\title{
Application Counseling Cognitive Behavioral With Modeling Techniques In Setting Lesson Study To improve Self Aggresion In Class X MIA 1 Students Of SMA N 1 Sukasada
}

\author{
Indah Safitri, I Ketut Gading, Nyoman Dantes \\ Universitas Pendidikan Ganesha \\ e-mail: indahsafitri1097@gmail.com
}

Received July, 03, 2018 Revised September, 08, 2018 Accepted Agustus, 12, 2019 Published Online September, 03, 2019

\section{Conflict of Interest Disclosures: \\ The authors declare that they have no significant competing financial, professional or personal interests that might have influenced the performance or presentation of the work described in this manuscript.}

Abstract : This study aims to determine the effectiveness of cognitive behavioral counseling with Modeling techniques in lesson study settings to intervene in student self-aggresion. The experimental design used was Pretest Postest Control Group Design. The sample of this study was class X MIA 1 SMA Negeri 1 Sukasada which was taken randomly from 6 class members of the population. The self aggresion data collection in this study used the Self Aggresion questionnaire. Hypothesis testing is carried out using the t-test. The results of the t-test obtained by thit amounted to 15.20 with a significance of $<0.001$. It identified that cognitive behavioral counseling with Modeling techniques in effective lesson study settings to intervene in self aggresion of students X MIA 1 Sukasada 1 Public High School.

Keywords: counseling cognitive behavioral, modeling, self-aggresion

Abstrak: Penelitian ini bertujuan untuk mengetahui efektifitas konseling kognitif behavioral dengan teknik Modeling dalam setting lesson study untuk mengintervensi self aggresion siswa. Desain eksperimen yang digunakan adalah Pretest Postest Control Group Design. sampel penelitian ini adalah siswa kelas X MIA 1 SMA Negeri 1 Sukasada yang diambil secara acak dari 6 kelas anggota populasi. Pengumpulan data self aggresion dalam penelitian ini menggunakan kuesioner Self Aggresion. Pengujian hipotesis dilaksanakan dengan menggunakan uji-t. Hasil uji-t yang diperoleh $t_{\text {hit }}$ sebesar 15.20 dengan signifikansi sebesar $<0.001$ hal ini mengidentifikasi bahwa konseling kognitif behavioral dengan teknik Modeling dalam setting lesson study efektif untuk mengintervensi self aggresion siswa X MIA 1 SMA Negeri 1 Sukasada

Kata kunci: konseling kognitif behavioral, modeling, self aggresion

How to Cite: Indah Safitri, I Ketut Gading, Nyoman Dantes. (2018). Application Counseling Cognitive Behavioral With Modeling Techniques In Setting Lesson Study To Invervene Self Aggresion In Class X MIA 1 Students Of SMA N 1 Sukasada. Bisma the journal of counseling, 2(2). 


\section{PENDAHULUAN}

Perilaku agresifitas siswa dalam kehidupan di sekolah memiliki karakteristik yang berbeda-beda. Perilaku agresif sebenarnya bukan hanya masalah kekerasan seperti tawuran semata, tetapi banyak perilaku agresif yang dimulai dari agresi yang berupa perkataan (verbal), ataupun olok-olokan yang dirasa menyakitkan individu dan berakhir pada tindakan agresi fisik berupa pemukulan, penusukan, perkelahian yang berujung pada tindakan kriminalitas.

Perilaku agresi ini dibagi dalam tiga klasifikasi yaitu: (1) fisik dan verbal, (2) aktif dan pasif, (3) langsung dan tidak langsung. Terjadinya tindakan agresif karena seseorang tidak bisa mengendalikan emosi yang ada dalam dirinya. Sikap agresif yang dipicu karena rasa marah dan dendam akan sangat mudah muncul. Oleh karena itu penting bagi siswa untuk dapat memahami, dan mengintervensi Selfaggresion yang ada dalam diri masing-masing.

\section{Self Aggresion}

Self Aggresion adalah kebutuhan untuk menyerang orang lain meliputi menyerang sudut pandang yang bertentangan, menceritakan kepada orang lain apa yang di pikirkan dan menertawakan orang lain, (Dharsana :2014 :2). Dari definisi tersebut menunjukkan beberapa indicator sebagai berikut: (1) menyerang sudut pandang yang bertentangan (2) menceritakan kepada orang lain apa yang di pikirkan (3) menertawakan orang lain

Menurut ahli berikutnya Self aggresion adalah kebutuhan untuk mengeluarkan luapan emosi sebagai reaksi terhadap kegagalan Individu yang ditampakkan dalam bentuk pengrusakan terhadap orang atau benda dengan unsur kesengajaan yang diekspresikan dengan kata-kata (verbal) dan perilaku (non-verbal) (Scheneiders :1964). Dari definisi tersebut menunjukkan beberapa indicator (1)mengeluarkan luapan emosi (2) pengrusakan terhadap orang atau benda(3)kesengajaan yang diekspresikan dengan verbal dan non verbal.

\section{Proses Terbentuknya Self Aggresion}

Terbentuknya perilaku agresif melibatkan banyak faktor. Pembahasan tentang faktor-faktor penyebab munculnya atau terbentuknya perilaku agresif juga amat tergantung dari sisi pendekatan yang digunakan. Setidaknya ada empat pendekatan utama untuk memahami beberapa penyebab munculnya perilaku agresif ini, yaitu

1). Pendekatan biologis terbentuknya perilaku agresif terkait dengan kondisi hormon testosterone dalam diri individu. Ada juga pandangan biologis yang lain, yang meyakini bahwa perilaku agresif juga bisa disebabkan karena abnormalitas anatomis, misalnya kelainan pada jaringan syaraf otak.

2). Pendekatan psikologis perilaku agresif dari sisi psyche (jiwa) manusia dengan mempertimbangkan elemen-elemen sosial (kemasyarakatan) yang melingkupi individu perspektif psikoanalisis seperti yang dijelaskan oleh Freud bahwa dalam diri manusia selalu mempunyai potensi bawah sadar yaitu suatu dorongan untuk merusak diri

3). Pendekatan situasional terbentuknya perilaku agresif melibatkan faktorfaktor (stimulus-stimulus) eksternal sebagai determinan-determinan dalam pembentukan agresi.

4). Pendekatan sosio-ecological terbentuknya perilaku agresif dan kepribadian individu sangat dipengaruhi oleh lingkungan dimana ia tinggal dan faktor social dalam lingkup keluarga perilaku anak tidak sesuai dengan keinginan orang tua juga dapat menyebabkan anak menjadi agresif karena secara tidak langsung orang tua telah mengajarkan bahwa apabiladi dalam kehidupan ada individu lain yang berbeda dengan keinginannya maka perlu diselesaikan dengan kekerasan (agresi). 


\section{Pengertian Kognitif Behavioral}

Konseling Kognitif Behavioral merupakan teori konseling yang menekankan pada pikiran dan tingkah laku. Kognitif Behavioral adalah teori konseling yang menekankan pada tingkah laku dan kognitif manusia yang pada dasarnya dibentuk dan ditentukan oleh lingkungan dan segenap tingkah lakunya itu dipelajari atau diperoleh karena proses latihan dan pemikiran. Sejalan dengan pendapat tersebut seorang ahli berpendapat bahwa konseling kognitif behavioral berfokus pada pikiran dan tingkah laku (Ketut Dharsana, 2017).

Kognitif Behavioral yaitu teknik modifikasi perilaku dan mengubah keyakinan maladaptif. Ahli terapi membantu individu mengganti interpretasi yang irasional terhadap suatu peristiwa dengan interpretasi yang lebih realistik. Atau, membantu pengendalian reaksi emosional yang terganggu, seperti kecemasan dan depresi dengan mengajarkan mereka cara yang lebih efektif untuk menginterpretasikan pengalaman mereka

Adapun beberapaa teknik-teknik konseling Kognitif Behavioral:

1) Operant Conditioning

2) Flooding

3) Assertivness dan Social Skill Training

4) Modeling

5) Contigency Contracting

6) Cognitive Restructuring

\section{Teknik Modeling}

Istilah modelling berasal dari bahasa inggris yang artinya mencontoh, meniru, memperagakan, atau menteladani. Menurut (Ketut Dharsana, \& Kadek Suranata, 2014) Teknik Modeling merupakan salah satu teknik konseling dimana seseorang belajar membuat dan menerapkan perilaku baru melalui proses pengamatan, mengobservasi, menggeneralisir perilaku orang lain (model), dimana dalam modeling ini juga melibatkan proses kognitif dan kreatif bukan semata-mata meniru/imitasi saja.

Teknik ini konseli dapat mengamati seseorang yang dijadikan modelnya untuk berperilaku kemudian diperkuat dengan mencontoh tingkah laku sang model. Dalam hal ini, konselor dapat bertindak sebagai model yang akan ditiru oleh konseli

Macam-macam modelling (pencontohan) menurut Corey ada 3 yaitu:

1. Model yang nyata (live model), contohnya konselor yang dijadikan sebagai model oleh konselinya, atau guru, anggota keluarga atau tokoh lain yang dikagumi

2. Symbolik modeling membentuk gambaran orang tentang realitas sosial diri, dengan cara itu dapat memotret berbagai hubungan manusiadan kegiatan yang mereka lakukan

3. Model ganda (multiple model) yang terjadi dalam kelompok. Seseorang anggota dari suatu kelompok mengubah sikap dan mempelajari suatu sikap baru, setelah mengamati bagaimana anggota lain dalam kelompoknya bersikap.

\section{METODE PENELITIAN}

Jenis penelitian yang digunakan dalam penelitian ini adalah rancangan penelitian pretest-postest control group design" hal ini dikarenakan peneliti melakukan perlakuan (treatmen) terhadap suatu Kelas dan dilakukan suatu prestest sebelum perlakuan diberikan. Sampel penelitian ini adalah siswa kelas X MIA 1 SMA Negeri 1 Sukasada, yang diambl secara acak dari 6 kelas anggota populasi.

Dari data awal yang diperoleh, sebagian siswa menunjukkan Self Aggresion yang tinggi dan yang rendah dalam penerapan self Aggresion, maka dari itu peneliti berusaha mengintervensi self aggresion siswa dengan menerapkan konseling kognitif behavioral dengan teknik modeling. 
Untuk mengumpulkan data tentang self Aggresion siswa dan untuk memperoleh data yang akurat maka dalam penelitian ini menggunakan beberapa teknik pengumpulan data beserta masing-masing perangkat pengumpulan datanya yaitu: (1) Pedoman Observasi, (2) Pedoman Wawancara, (3) Kuisioner, (4) Buku Harian.

\section{HASIL DAN PEMBAHASAN}

Data yang digunakan dalam penelitian ini di dapatkan dari data hasil penyebaran kuisioner self aggresion pada kelas eksperimen yaitu kelas X MIA 1 dan kelas kontrol yaitu kelas X IBB 2 dengan mengambil tahap pretes dan juga postes.

Kemudian data pretes dan postes dari hasil kuisioner tersebut di analisis dengan uji-t untuk mencari perbedaan antara postes eksperimen dan postes kontrol. Proses perhitunganuji-t dalam penelitian ini menggunakan aplikasi JASP 10.0. Untuk mencari efektivitas dilanjutkan dengan menggunakan rumus effect size.

\section{Uji-t}

Untuk mengukur perbedaan antara data kelas kontrol dan kelas eksperimen dalam penelitian ini digunakan uji-t. Berdasarkan uji-t yang dilaksanakan peneliti didapatkan $t_{\text {hit }}$ sebesar 15.206 dengan signifikansi $<0.01$. Dengan rincian seperti yang diuraikan di bawah ini pada tabel 01 .

Tabel 01. Hasil Perhitungan data dengan menggunakan Aplikasi JASP 10.0

\begin{tabular}{|c|c|c|c|c|}
\hline \multicolumn{5}{|c|}{ Independent Samples T-Test } \\
\hline \multicolumn{3}{|r|}{$\mathrm{df}$} & $\mathrm{p}$ & Cohen's d \\
\hline $\begin{array}{l}\text { Poste } \\
\text { st }\end{array}$ & 15.206 & 49.00 & $<.001$ & 4.266 \\
\hline \multicolumn{5}{|c|}{ Note. Student's t-test. } \\
\hline \multicolumn{5}{|c|}{$\begin{array}{l}\text { a Levene's test is significant }(p<.05) \text {, } \\
\text { suggesting a violation of the equal variance } \\
\text { assumption }\end{array}$} \\
\hline
\end{tabular}

\section{Uji Efektivitas}

Menyatakan treatmen atau perlakuan memiliki dampak tidak cukup dengan mengukur perbedaan hasil setelah treatmen maka dari itu dalam penelitian ini, peneliti juga melakukan uji efektivitas dengan rumus sebagai berikut:

$$
E s=t \sqrt{\frac{1}{n_{1}}+\frac{1}{n_{2}}}
$$




$$
\begin{aligned}
& E s=t \sqrt{\frac{1}{24} \frac{1}{27}} \\
& E s=15.20 .0 .038 \\
& E s=0.57
\end{aligned}
$$

Dengan memasukan $t_{\text {hit }}$ yang telah diperoleh dari perhitungan Uji-t sebelumnya peneliti melakukan perhitungan uji efektivitas. Berdasarkan hasil perhitungan diperoleh angka untuk uji efektivitas sebesar 0.57. Dengan demikian dalam penelitian ini $\mathrm{H}_{0}$ yang berbunyi "Konseling kognitif Behavioral dengan Teknik modeling tidak efektif dalam mengintervensi Self aggresion siswa" dinyatakan ditolak. Sedangkan $\mathrm{H}_{\mathrm{a}}$ yang berbunyi "Konseling kognitif Behavioral dengan Teknik modeling efektif dalam mengintervensi Self aggresion siswa" dinyatakan diterima.

\section{PENUTUP}

\section{Kesimpulan}

Hasil penelitian ini menunjukkan bahwa Self Aggresion siswa yang mengikuti konseling Teori konseling kognitif behavioral dengan teknik modeling lebih meningkat dan signifikan. Berdasarkan pernyataan ini dapat kita katakan bahwa Teori konseling kognitif behavioral dengan teknik modeling tepat diterapkan di sekolah untuk mengintervensi agresifitas siswa.

\section{Saran}

Adapun beberapa saran yang ingin disampaikan terkait dengan penelitian yang sudah dilakukan, yaitu:

1. Bagi Kepala Sekolah

Diharapkan kepada kepala sekolah selalu berdiskusi dengan semua wali kelas dan guru-guru lainnya, sehingga semua permasalahan yang terjadi pada siswa lebih cepat diketahui dan dapat segera ditangani.

\section{Bagi Guru BK}

Konseling behavioral dengan teknik modeling merupakan suatu layanan BK yang sangat efektif untuk membantu siswa dalam menangani permasalahan yang dihadapi siswa. Selain itu layanan konseling perlu dilaksanakan secara berkesinambungan dengan tujuan untuk mengetahui perkembangan siswa disekolah.

\section{Bagi Semua Guru}

Guru hendaknya dalam proses pembelajaran selalu menunjukkan sikap yang hangat dan terbuka agar siswa merasa nyaman untuk mengikuti proses pembelajaran dan tercipta suasana yang kondusif. Berkualitasnya proses pembelajaran tergantung dari guru dan siswa. Apabila guru menjelaskan tugasnya dengan baik dan penuh tanggung jawab maka proses belajar mengajar akan terealisasikan dengan baik, begitu pula sebaliknya apabila siswa menyadari tugas dan kewajibannya sebagai seorang siswa niscaya prestasi yang diperoleh akan memuaskan. 


\section{Bagi Siswa}

Kepada siswa siswi kelas X MIA 1 SMAN Sukasada disarankan supaya lebih mampu mengintervensi self aggresion yang dimilikinya.

5. Bagi Peneliti

Peneliti diharapkan dapat menerapkan disekolah setelah penelitian ini selesai

\section{DAFTAR PUSTAKA}

Adi, K., Ananda, C., Dharsana, I. K., \& Suarni, N. K. (2017). Cognitive Behavioral Counseling with Modelling Pan Balang Tamak to Improve Persuasive, 1(2), 60-68. https://doi.org/10.23887/128162017

Damayanti, R., \& Aeni, T. (2016). Efektivitas Konseling Behavioral Dengan Teknik Modeling Untuk Mengatasi Perilaku Agresif Pada Peserta Didik Smp Negeri 07 Bandar Lampung, 3(1), 1-10. Retrieved From

\section{Http://Ejournal.Radenintan.Ac.Id/Index.Php/Konseli/Article/Viewfile/572/1257}

Dantes, N. (2012a). Metode penelitian. Yogyakarta: Andi Offset.

Dantes, N. (2012b). Metodologi Penelitian. Yogyakarta: Penerbit Andi.

Dharsana. (2014). Model-Model Teori, Teknik, Skill Bimbingan Konseling untuk Penulisan RPBK, Proposal, Sripsi. Tesis. Singaraja: BK FIP Undiksha.

Dharsana, I. K. (2007). Dasar-Dasar Konseling Seri 2. Singaraja: Jurusan Bimbingan dan Konseling Fakultas Ilmu Pendidika Universitas Pendidikan Ganesha.

Dharsana, K. (2013). Modul Teori-Teori Konseling. Singaraja: Jurusan Bimbingan Konseling, Fip Undiksha.

Dharsana, K. (2014a). Model-Model Teori, Teknik, Skill Bimbingan Konseling untuk Penulisan RPBK, Proposal, Sripsi. Tesis. Singaraja: Bk Fip Undiksha.

Helida, Nyoman Dantes, M. S. (2014). Hubungan Intensitas Interaksi Dalam Pola Asuh Orang Tua Dan Konsep Diri Dengan Kecenderungan Perilaku Agresif Pada Siswa Kelas Xi Sma Negeri 4 Singaraja, 2(1)

Retrieved

From Https://Ejournal.Undiksha.Ac.Id/Index.Php/JJBK/Article/Viewfile/3716/2975

Kamaludin, H. (2011). Bimbingan Dan Konseling Sekolah, 17, 447-454. Retrieved From

\section{Http://Jurnaldikbud.Kemdikbud.Go.Id/Index.Php/Jpnk/Article/View/40}

Koyan, I. W. (2009). Statistik Dasar dan Lanjut (Teknik Analisis Data Kuantitatif). Singaraja: Universitas Pendidikan Ganesha.

Luh, N., Yudayanti, S., Nengah, N., Antari, M., Dantes, N., \& Konseling, J. B. (2014). Keterampilan Dalam Berkomunikasi Interpersonal Siswa Kelas X Mia 2 Sma Negeri 3 Singaraja. Retrieved From 


\section{File:///C:/Users/User/Downloads/35-3657-1-SM.Pdf}

Mulyaningsih, I. E. (2014). Pengaruh Interaksi Sosial Keluarga, Motivasi Belajar, Dan Kemandirian Belajar Terhadap Prestasi Belajar. Pendidikan Dan Kebudayaan, 441-451.

\section{Http://Jurnaldikbud.Kemdikbud.Go.Id/Index.Php/Jpnk/Article/Viewfile/156/144}

Nursafitri, R., Setiawati, D., \& Interpersonal, H. (2012). Penerapan bimbingan kelompok dengan teknik sosiodrama untuk membantu meningkatkan kemampuan hubungan interpersonal siswa.

\section{http://jurnalmahasiswa.unesa.ac.id/article/5655/13/article.pdf}

Sari, I. puspita. (2015). Pengembangan Layanan Informasi Teknik Symbolic Model Dalam Membantu Mengembangkan Kemandirian Belajaranak Usia Sekolah Dasar Indah. Pentingnya Pemahaman Kedudukan Dan Fungsi Bahasa Indonesia Sebagai Pemersatu Negara Kesatuan Republik Indonesia, 1(1), 234-242.

\section{Article Information (Supplementary)}

\section{Conflict of Interest Disclosures:}

The authors declare that they have no significant competing financial, professional or personal interests that might have influenced the performance or presentation of the work described in this manuscript.

Copyrights Holder: < authors > <year >

First Publication Right: BISMA The Journal of Counseling

https://doi.org/10.xxxx/xxxxx

Open Access Article | CC-BY Creative Commons Attribution 4.0 International License. 